\title{
Morphological and molecular identification of cellulolytic fungi associated with local raru species
}

\author{
DENI ELFIATI ${ }^{1, \bullet}$, ARIDA SUSILOWATI ${ }^{1}$, CELVIA MODES ${ }^{1}$, HENTI HENDALASTUTI RACHMAT ${ }^{2}$ \\ ${ }^{1}$ Faculty of Forestry, Universitas Sumatera Utara. Jl. Tri Dharma Ujung No. 1, Kampus USU, Medan 20155, North Sumatra, Indonesia. \\ Tel./fax.:+62-61-820-1920.`email: denielfiati@yahoo.com \\ ${ }^{2}$ Forest Research, Development and Innovation Agency Ministry of Environment and Forestry. Jl. Gunung Batu No. 5. PO Box 165, Bogor 16001, \\ West Java, Indonesia
}

Manuscript received: 1 July 2019. Revision accepted: 27 July 2019.

\begin{abstract}
Elfiati D, Susilowati A, Modes C, Rachmat HH. 2019. Morphological and molecular identification of cellulolytic fungi associated with local raru species. Biodiversitas 20: 2348-2354. This study is aimed to isolate and identify cellulolytic fungi from different local Raru species in Central Tapanuli, North Sumatra, Indonesia. Cellulolytic fungi are fungi that can degrade natural polymer materials such as cellulose. The fungal species were isolated from soil under three local raru species. The samples inoculating (1 mL) from serial dilutions (10-2 to 10-5) on Carboxy Methyl Cellulose (CMC) plates. The plates were incubated at $28^{\circ} \mathrm{C}$ for one week, then the fungal colonies were observed and pure cultures were maintained. Fungi with cellulolytic activity were characterized by the formation of clear zones around the colonies on CMC media plus congo red $(0.1 \%)$. The identification of fungi was carried out by molecular identification of the isolated fungi at the species level. The extracted fungal DNA was amplified by PCR using specific internal transcribed spacer primer (ITS1/ITS4). The PCR products were sequenced and compared with the other related sequences in Gen Bank (NCBI). 20 isolates were successfully isolated and nine isolates had cellulolytic activity. Six fungal species from 20 isolates were identified as: Aspergillus sp., Penicillium sp., Aspergillus terreus, Penicillium mariae-crucis, Aspergillus tanneri and Penicillium citrinum. The results showed that Aspergillus terreus was the most abundant fungus obtained from all the raru stand.
\end{abstract}

Keywords: Aspergillus terreus, cellulolytic fungi, internal transcribed spacer, molecular identification, morphology

\section{INTRODUCTION}

Raru is the name of bark produced by members of the Dipterocarpaceae family endemically distributed in several locations in Indonesia, i.e., North Sumatra, Riau, West Kalimantan, East Kalimantan and South Kalimantan Provinces. As with other Dipterocarpaceae species, raru has a high wood quality with a strong and durable class that can be used as building materials and main construction. However, some people, especially Bataknese ethnic, cut the raru trees for bark purpose without any cultivation efforts (Susilowati et al. 2019). This condition causes the decreases of raru population in nature. In 1998, the International Union for Conservation Nature (IUCN) classified one raru producing tree species, namely Cotylelobium melanoxylon into the red list species with an endangered status (Ashton 1998), but in 2019, the status was revised into a least concern status (Barstow 2019). So, immediate effort is needed to prevent this species from extinction.

The survival of a species is determined by the genetic ability of a species and environment/habitat that supports its growth. If the two components do not synergize, then the chances of species extinction will be greater (Brigg 2015). Soil organisms affect the growth of plants and other living organisms. Plants can strongly influence the activity and composition of the community of rhizosphere microorganisms (Rodriguez-Lionaz et al. 2008). Conversely, plant growth can be limited or driven by the presence of soil microorganisms. Plants determine the composition, abundance, and activity of biological regulators and ecosystem engineers, while microbial functional diversity determines the productivity and composition of vegetation on it.

Fungus is one of the most diverse microorganisms that inhabit different environmental sources such as soil, plant parts (leaves, root, and fruits), water and food sources (Maheswari and Komalavalli 2013, Sartori et al. 2013; Rebecca et al. 2012). The growth and distribution of fungi are affected by different environmental factors such as temperature, $\mathrm{pH}$, moisture, degree of aeration, amount and type of nutrients (Gaddeyya et al. 2012). Soil fungi play an important and vital role in maintaining soil fertility and productivity, and are influenced by a number of factors, including soil properties and human activities (Bao et al. 2012). Fungi are very important organisms that inhabit the soil. They play an important part in nutrition and processes that lead to the improvement of the health and development of the plant (Mulani and Turukmane 2014). Cellulolytic fungi are one of the fungi that play a role in the process of decomposition of organic matter. Cellulolytic fungi decompose organic material containing cellulose by producing cellulase enzymes (Tuli et al. 2015; Ahmed et al. 2018). Some fungi producing cellulase enzymes include the genus Aspergillus, Trichoderma, Penicillium, Acremonium, Rhizopus, Chaetomium, Curvularia (Reddy et al. 2014; Torres et al. 2014). Fungi also potential for medicines, herbicides, insecticides, and biological fertilizers. 
The morphology of filamentous fungi can be characterized by its fibers (hypha), that are cylindrical, threadlike $2-10 \mu \mathrm{m}$ in diameter structures, up to several centimeters long, with different colony features such as color, size, shape, visible by the naked eye which was used classically to identify fungi (Lima and Borba 2001). The morphology of fungi was observed under a compound microscope to examine the shapes forming from the arrangement of spores (Gaddeyya et al. 2012). Molecular identification techniques based on total fungal DNA extraction provide a unique barcode for the determination and identification of different fungal isolates up to a species level (Landeweert et al. 2003). Molecular identification using this barcode has turned into an essential tool for mycologists studying fungal taxonomy, molecular evolution, population genetics or fungus-plant interactions (Moller et al. 1992). The identification of fungi using molecular techniques is carried out by the sequencing of PCR amplified part of 18S rRNA genes with universal primers to fungal species (Monod et al. 2005; Hensel and Holden 1996). Molecular identification of fungi in this research was carried out by using ribosomal DNA sequences (rDNA), more specifically the ITS (Internal Transcribed Spacer region) region. The ITS rDNA area that is suitable for species identification diagnostics and phylogenetic analysis is the area of ITS-1 and ITS-4 which together flank the 5.8S rDNA of fungi and other microorganisms (Kubicek et al. 2008). Identification and management of fungi both ecologically and genetically would be one tool to prevent their extinction, especially for local species of North Sumatra. This research was conducted to identify cellulolytic fungi isolated from rhizosphere of raru (Cotylelobium spp.). Soils in rhizosphere of raru can potentially support several microbes with high cellulolytic enzymes. Therefore exploration in microbe communities under raru stand can be useful for biotechnology and for ecological conservation.

\section{MATERIALS AND METHODS}

\section{Soil Sampling and Soil Analysis}

The samples were taken from Bona Lumban Village, Tukka Subdistrict, Central Tapanuli District, North Sumatra Province, Indonesia. Soil samples were taken as a composite at a depth of $0-20 \mathrm{~cm}$, around the roots of raru trees (raru dahanon, raru songal and raru pulut). These three local raru species were identified based on their morphological characteristic (canopy shape, leaf, stem, bark, resin, wood color) and local farmer information (data not shown). The collected soil was put into plastic and taken to the laboratory for further analysis. Soil chemical properties analysis was performed for soil $\mathrm{pH}$ by using a glass electrode method, soil available $\mathrm{P}$ content by using Bray 2 method, organic $\mathrm{C}$ content by using Walkley and Black method, total soil $\mathrm{N}$ content by using Kjehldahl method and cation exchange capacity by using washing ammonium acetate method (Soil Research Center 2005).

\section{Isolation and culture of cellulolytic fungi}

Serial dilution of soil sample were made and $10^{-3}$ to $10^{-6}$ dilutions were plated into carboxyl methylcellulose (CMC) media with the composition as follow: $0.5 \mathrm{~g} \mathrm{KH}_{2} \mathrm{PO}_{4}, 0.2 \mathrm{~g}$ $\mathrm{MgSO}_{4} .7 \mathrm{H}_{2} \mathrm{O}, 0.1 \mathrm{~g} \mathrm{NH}_{4} \mathrm{NO}_{3}, 0.02 \mathrm{~g} \mathrm{FeSO}_{4} .7 \mathrm{H}_{2} \mathrm{O}, 0.05 \mathrm{~g}$ $\mathrm{Ca}\left(\mathrm{NO}_{3}\right)_{2} \cdot 4 \mathrm{H}_{2} \mathrm{O}, 15 \mathrm{~g}$ agar and $10 \mathrm{~g}$ carboxymethylcellulose (CMC) per liter of distilled water with 50 mg kanamycin and pH 5.0 (Torres et al. 2014) . Fungal cultures were incubated at $28^{\circ} \mathrm{C}$ for 7 days. The fungi were then isolated, purified and stored for further testing.
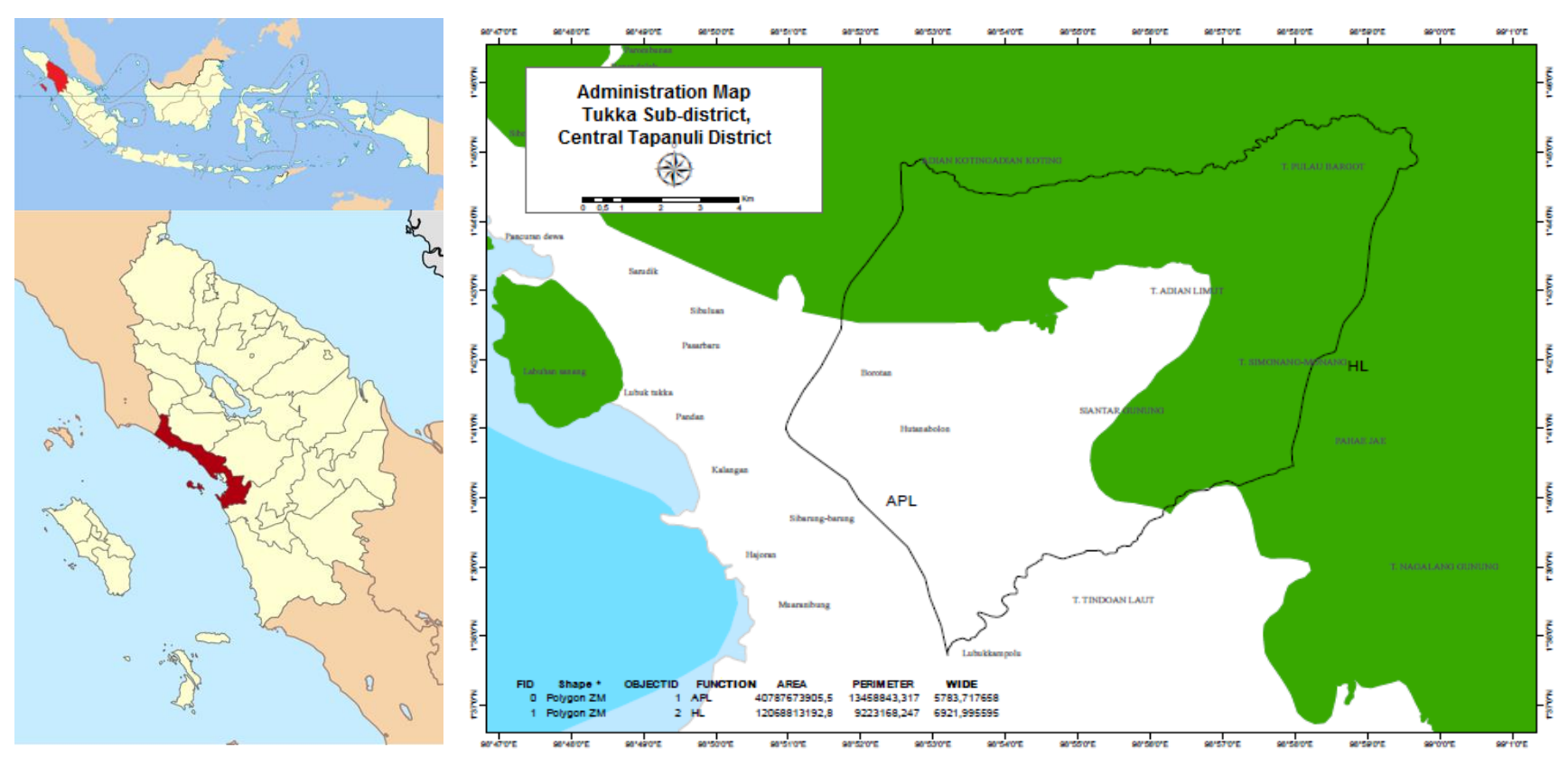

Figure 1. Map of research location in Tukka Subdistrict, Central Tapanuli District, North Sumatra, Indonesia 


\section{Qualitative determination of cellulolytic activity}

Qualitative determination of cellulolytic activity was achieved by growing the fungi in CMC media added with congo red $(0.1 \%)$ (Torres et al. 2014). Fungi exhibiting cellulolytic activity are characterized by the formation of a clear zone around the colony. The width of the clear zone is calculated by subtracting the diameter of the clear zone from the diameter of the colony (Saraswati et al. 2007).

\section{Morphology and molecular identification of cellulolytic fungi}

Identification of fungi was done by observing the fungi both macroscopically and microscopically. Fungi were identified to the genus level (Gilman1971; Gandjar et al. 1999). Fungi were grown on potato dextrose agar (PDA) and incubated for 7 days at $28^{\circ} \mathrm{C}$. This part of the study was conducted at the Microbiology Laboratory, Forest Research Development and Innovation Agency-Ministry of Environment and Forestry Innovation. The research materials were fungal isolates collected from soil rhizosphere under raru stands $(0-20 \mathrm{~cm}$ depth). Molecular identification was done by using ITS- 1 rDNA primers (5'TCC GTA GGT GAA CCT TGC GG 3') according to White et al. (1990) and the ITS 4 primers (5' TCC TCC GCT TAT TGA TAT GC 3') according to the White et al. (1990). The research steps included DNA isolation and 5.8 SrDNA gene amplification, PCR product purification, sequencing, precipitation, sequence detection, and sequence analysis.

\section{Isolation and amplification of 5.8 S rDNA}

The soil fungi were isolated by the soil dilution method. One gram of the soil sample was suspended in $10 \mathrm{ml}$ of sterile distilled water to make serial dilutions $\left(10^{-1}\right.$ to $\left.10^{-5}\right)$. One $\mathrm{mL}$ of each dilution was placed on Potato Dextrose Agar (PDA) containing 1\% streptomycin. The plates were incubated at $28^{\circ} \mathrm{C}$ in the dark. The plates were observed for one week to identify the fungal growth (Gaddeyya et al. 2012; Reddy et al. 2014). The DNA Extraction of genomic DNA from the fungi was conducted from a one-week-old PDA culture using DNeasy Plant Mini Kit (Supplied by QIAGEN). Primers (ITS1and ITS4) were used to amplify ribosomal internal transcribed spacer (ITS). PCR products were purified using the QIA quick PCR purification kit (Bao et al. 2012).

\section{Sequencing and analysis}

Detection of sequencing results was done by adding 40 SLS as a solvent. Sequence detection process was carried out by capillary electrophoresis on the CEQ 8000 Genetic Analyzer from Beckman sequencer. The sequencing product is I form of a nucleotide base sequences. The sequencing products were then aligned with GenBank data using the BLAST-N (Basic Local Alignment Search ToolNucleotide) program to determine the nucleotide similarity of the species of the isolates tested. The program for this analysis is available online from the NCBI website (National Center for Biotechnology Information). Relationship between the isolates was analyzed based on tree phylogenetic construction. The isolated DNA sequences were aligned using the ClustalW2 multiple sequences alignment program from the European Bioinformatics Institute (EBI).

\section{RESULTS AND DISCUSSION}

\section{Soil analysis}

Soils from the rhizosphere region of the three local raru trees namely dahanon, songal and pulut have acidic $\mathrm{pH}$ with $\mathrm{pH}$ values of $4.5,4.7$ and 4.9 respectively. The C organic contents were categorized as high criteria in the songal rhizosphere $(3.03 \%)$ and pulut rhizosphere $(4.96 \%)$ and were very high in the dahanon rhizosphere $(5.64 \%)$. Available $\mathrm{P}$ was included in very low criteria for songal raru $(1.23 \mathrm{ppm})$ and pulut raru $(3.08 \mathrm{ppm})$ and medium criteria for dahanon soil $(8.88 \mathrm{ppm})$. The total soil $\mathrm{N}$ content was categorized as low $(0.19 \%)$ in songal raru and medium criteria $(0.27 \%$ and $0.25 \%)$, respectively, on the dahanon and pulut raru. Low cation exchange capacity was found in all three types of raru. Soil reactions $(\mathrm{pH})$ generally affect the availability of nutrients and the presence of microbes in the soil. Soils with $\mathrm{pH}$ 6-7 have higher nutrient availability, so they can be available to plants. The presence of microbes in the soil depends on the soil type and characteristics. Bacteria are generally more dominant in soil with a $\mathrm{pH}$ of more than 7 , while fungi are more dominant in soils with acidic $\mathrm{pH}$ ( $\mathrm{pH}$ less than 5.5). In addition, microbes in the soil also need nutrients for their survival. Microbes in the soil are generally heterotrophic, which requires organic matter as an energy source and carbon source. In forest ecosystems, the presence of organic matter is the key to ecosystem sustainability and forest productivity. Organic material presents on the surface of the soil called the 'forest floor' is a source of nutrients in the forest ecosystem. Thus, the presence of raru trees and the litter they produce provides cellulose so as to maintain the existence and survival of microbes under the raru stands.

\section{Isolation and qualitative determination of cellulolytic activity}

Twenty isolates from raru rhizosphere region were isolated, five isolates from rhizosphere of songal raru trees, seven isolates from rhizosphere of soil dahanon raru trees and eight isolates from rhizosphere of soil pulut raru trees. Nine isolates had cellulolytic activity characterized by formation of a clear zone around the colony (Figure 1). The nine isolates included four isolates from rhizosphere of raru songal, three isolates from rhizosphere of raru dahanon, and two isolates from rhizosphere of raru pulut. The width of the clear zone ranged from 0.09 to $0.41 \mathrm{~cm}$, where the 8FRS isolate had the largest clear zone width (Table 1).

\section{Morphological identification}

Morphological identification carried out by observing macroscopic and microscopic characters and revealed that nine fungi that have cellulolytic activity belong to 2 genera, namely Aspergillus (5 isolates) and Penicillium (4 isolates) (Table 1). 
Table 1. The width of the clear zone of cellulolytic fungi from rhizosphere of raru tree and name of the fungal genus based on morphological identification

\begin{tabular}{ccl}
\hline $\begin{array}{c}\text { Fungal isolate } \\
\text { code }\end{array}$ & $\begin{array}{c}\text { Clear zone width } \\
(\mathbf{c m})\end{array}$ & Genus \\
\hline 1 FRS & 0.10 & Aspergillus \\
2FRD & 0.09 & Aspergillus \\
3FRD & 0.18 & Penicillium \\
4FRP & 0.10 & Aspergillus \\
6FRS & 0.12 & Penicillium \\
7FRS & 0.11 & Aspergillus \\
8FRS & 0.41 & Penicillium \\
9FRD & 0.20 & Aspergillus \\
10FRP & 0.21 & Penicillium \\
\hline
\end{tabular}

\section{Aspergillus}

Aspergillus is a type of fungus commonly found in tropical regions with black, green, brown and yellow colonies (Gilman 1971; Gandjar et al. 1999) (Figure 2). There were 5 isolates identified as Aspergillus, and there were 2 types of colonies with different characteristics. The characteristics of the two colonies are as follows: (i) the colony grows rather slowly with a colony diameter of 0.5 $1.5 \mathrm{~cm}$, the colony grows thin on the agar surface, then turns white and looks rather wet. This type has semirounded colonies and round conidia. This type was identified as Aspergillus sp.1. Four isolates were found to have these characteristics and identified as Aspergillus sp., namely 1FRS, 7FRS, 4FRD, and 2FRD isolates; (ii) colonies grow semi-round and spread with round conidia. The diameter of the colony was $0.5-1.5 \mathrm{~cm}$ with yellow colonies. This type was identified as Aspergillus sp.2. There was only one isolate identified as Aspergillus sp.2, i.e., 9FRD isolate.

\section{Penicillium}

There were four isolates identified as Penicillium and there were 2 types of colonies with different characters. The colony type has the following characteristics: (i) colony diameter $1.5-2.5 \mathrm{~cm}$, colonies were white like velvet and grew like cotton in the middle. Colonies growth was semi-round with semi-round conidia and branched conidiophores. This isolate was identified as Penicillium sp.1. There were two isolates with these characteristics, namely 8FRS and 10FRP isolates; (ii) colony diameter of $0.5-2 \mathrm{~cm}$ with white and grayish colonies. The colonies of fungi grew round with round conidia and branched conidiophores. Isolates with these characteristics were identified as Penicillium sp.2. Two isolates were found to have these characters, i.e., 6FRS and 3FRD.

\section{Molecular identification}

\section{Isolate identity}

Detected 5.8 S rDNA sequences were 70 to $1230 \mathrm{bp}$ long. The ITS region of rDNA sequences is shown in Table 2. Sequence analysis of the ITS regions of nuclear-encoded rDNA showed a significant alignment of $84-100 \%$ with the previous isolated fungal species. The results of the $5.8 \mathrm{~S}$ rDNA sequence alignment revealed two genera of Aspergillus and Penicillium. Of these, one isolate was identified as Aspergillus sp., one isolate was Penicillium sp., 3 isolates were Aspergillus terreus, 2 isolates were Penicillium mariae-crucis, one isolate was Aspergillus tanneri isolate, one isolate was Penicillium citrinum (Table 2). ITS rRNA genes are excellent candidates for the phylogenetic analysis since they are universally distributed, functionally constant, sufficiently conserved, and of adequate length to provide a deep view of evolutionary relationships (Madigan et al. 2012). The nuclear rDNA internal transcribed spacer rDNA region (ITS1-5.8S-ITS2) is the official DNA barcode for fungi (Schoch et al. 2012) because it is the most frequently sequenced marker in fungi and has primers that work universally. As such, it is good practice to include ITS sequences whenever new species are described, although it sometimes does not contain enough variation for distinguishing among all species. Sixth species were identified using DNA barcoding with an identity range between $84-99 \%$. It is also proposed that ITS rDNA region sequence is one of the most important tools for the identification of the fungal species isolated from environmental sources (Anderson and Parkin 2007); hence, it has been widely used to detect the soil fungal community, and as an improvement of the classical identifications.

According to Table 2, all Aspergillus and Penicillium isolates were classified as Eurotiomycetes. Both Aspergillus and Penicillium are filamentous fungi, known as well adapted fungi in various environment and soil conditions. Aspergillus comprises a large group of filamentous, anamorph fungi classified into 837 species (Hawksworth 2011), which are human and plant pathogens (e.g. A. fumigatus, and A. avus), as well as producers of specific industrially important and bioproductss, e.g., $A$. niger, A. terreus and A. oryzae (David et al. 2006).

Due to the presence of various bioactive compounds and the capacity to produce specific proteins (e.g. enzymes such as $\alpha$-amylase, glucose oxidase, invertase, pectinase, proteinases, and glucose dehydrogenase) and other metabolites such as organic acids (e.g. citric, gluconic and itaconic acids), the members of Aspergillus genus are considered as ones of the most economically important genera of microfungi (Bennett et al. 1998; Punt et al. 2002; Krijgsheld et al. 2013). Moreover, the most active extracts obtained from Aspergillus sp. are subjected to phytotoxic and herbicidal activities.

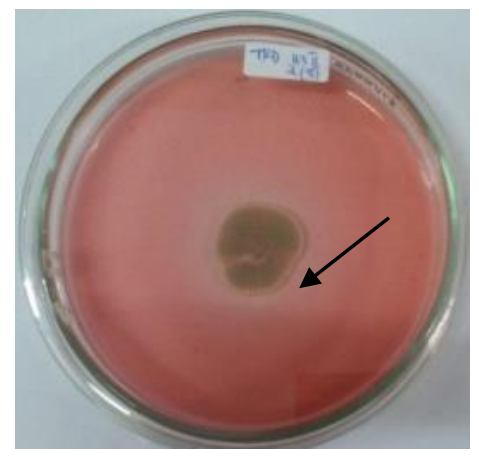

Figure 2. Clear zone (arrow) around the colony which indicates cellulolytic activity 


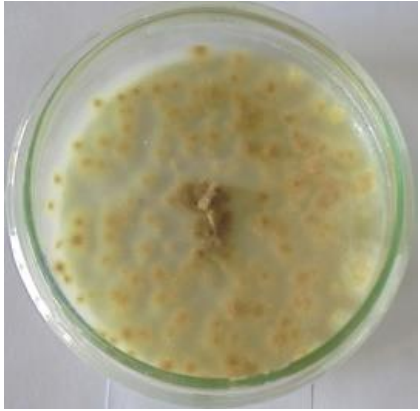

A

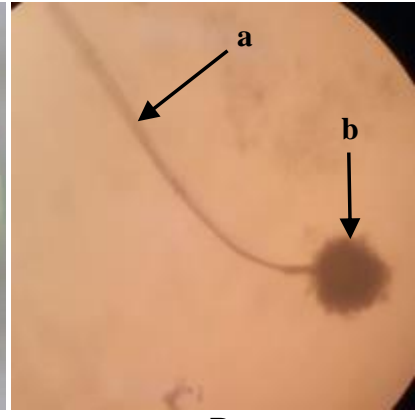

Figure 3. A. Colonies of Aspergillus on PDA media, B. Microscopic character: a. conidiophore, b. conidia

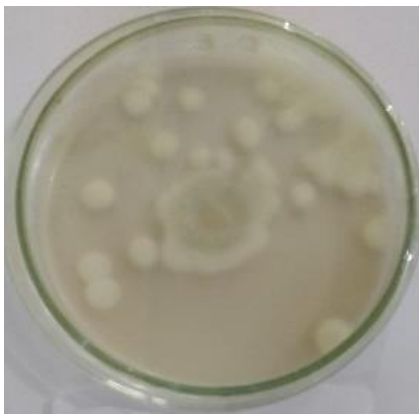

$\mathbf{A}$

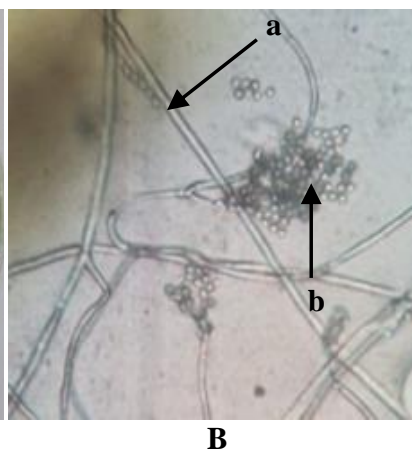

B
Figure 4. A. Penicillium colonies on PDA media, B. Microscopic character: a. conidiophore, b. conidia

Three different Aspergillus species was found in the present study, i.e, Aspergillus sp., Aspergillus terreus, and Aspergillus tanneri. Aspergillus terreus is a producer of secondary metabolites and is known for its compounds include aspulvinone, an active natural product capable of inhibiting influenza an H1N1 virus and asterriquinone, a metabolite for antitumor activity. A. terreus also known as prospective pigment producer for industrial purpose. A tanneri was new species that later found from genus Aspergillus and closely related to the members of Aspergillus section Circumdati (Sugui et al. 2012). Some research reported that $A$. tanneri was a pathogen that causes many diseases on human (Segal et al. 2009; Sugui et al. 2014).

Three species of Penicillium was found in this research. Penicillium is known for its ability to produce a number of compounds that possess many biological activities. Cholesterol-lowering activity of secondary metabolites from Penicillium species has spurred efforts towards the isolation of these fungi from different natural sources. Species of Penicillium are ubiquitous soil fungi, and their conidia are easily distributed in nature through the atmosphere and soil. Several reports have suggested that Penicillium spp. interact with roots of crop plants to enhance the plant growth (Hyakumachi1994; Shivanna et al. 1994; Khan et al. 2008). Penicillium is potent plant growth-promoting fungus, and secrete the plant hormones, indole-3-acetic acid (IAA) and GA, and involve in phosphate solubilization, which may be a reason to increase the plant growth (Khan et al. 2008; Kim et al. 2011; Radhakrishnan et al. 2013). Some species of Penicillium are well known for their antagonistic activity against pathogen by producing antibiotics and induce resistance in plants by activating multiple defense signals (Hossain et al. 2007).

Penicillium citrinum has been reported as common endophytic fungus of wheat and soybean plants. $P$. citrinum had been isolated from different environmental conditions, ranging from permafrost sediments to agricultural fields and forest soils. Penicillium citrinum was known as one of GA producer and also mycotoxin citrinin and cellulose digesting enzymes (Khan et al. 2008). P. citrinum also potential as phosphate solubilizing (Yadav et al. 2011). Penicillium mariae-crucis was also known as one of decomposer fungi for lignocellulolytic material. Several researchers reported that $P$. mariae-crucis was pathogenic fungi for human.

Table 2. Identification of fungal isolates of ITS region of rRNA gene sequence

\begin{tabular}{|c|c|c|c|c|}
\hline Fungal isolate & Species identified & Lenght & Identity & Accession number \\
\hline $1 \mathrm{FRS}$ & Aspergillus sp. & 1081 & $100 \%$ & MH741436.1 \\
\hline 6 FRS & Penicillium sp. & 1016 & $100 \%$ & KX067868.1 \\
\hline 7 FRS, 2FRD, 4FRP & Aspergillus terreus & 1068 & $100 \%$ & MH047280.1 \\
\hline 8 FRS, 10FRP & Penicillium mariae-crucis & 1022 & $100 \%$ & MH861585.1 \\
\hline 9 FRD & Aspergillus tanneri & 806 & $84 \%$ & JN853798.1 \\
\hline 3FRD & Penicillium citrinum & 968 & 100 & MH911355.1 \\
\hline
\end{tabular}

Table 3. Fungal Isolate distribution on different raru species

\begin{tabular}{llccc}
\hline Fungal isolate & Species identified & Raru songal & Raru dahanon & Raru pulut \\
\hline 1 FRS & Aspergillus sp. & + & - & - \\
6 FRS & Penicillium sp. & + & - & - \\
7 FRS, 2 FRD, 4 FRP & Aspergillus terreus & + & + & + \\
8 FRS, 10 FRP & Penicillium mariae-crucis & + & - & + \\
9 FRD & Aspergillus tanneri & - & + & - \\
3FRD & Penicillium citrinum & - & - & + \\
\hline
\end{tabular}




\section{Fungal distribution}

According to the current study results, the distribution and abundance of the fungi were different from one raru species to another. The distribution of the isolated species from different sources of raru stand is shown in Table 3. Raru songal has the highest number of fungi species whereas raru dahanon has the lowest number of fungi species. Based on Table 3, A.terreus was found in all local raru stands while Aspergillus sp., and Penicillium sp. were only found in songal raru stands, A. tanneri was only found in the dahanon raru stands, whereas Penicillium citrinum was only found in pulut raru stands.

The difference in the distribution of fungi in the three local types of raru is probably caused by differences in root exudates produced by the three types of raru. Metabolic activity and metabolites released by plants through roots determine condition of the microbiology of the soil in the root area. Plant species, plant growth phases and environmental conditions affect the amount and composition of exudates produced by the plant's roots (Meena et al. 2017). Differences in the number and composition of root exudates affect the composition, abundance or activity of the plant microbial community of the plant (Nath et al. 2017; Verma et al. 2017). Soil microbes utilize plant-derived substances (such as root exudates) which consist of various compounds (such as organic acids, sugars, vitamins, and amino acids) as the main nutrients for their growth and development (Verma et al. 2010, 2017).

\section{Discussion}

The results showed that the soil in the rhizosphere of raru trees had good potential as a source of cellulolytic fungi, because the soil has high to very high organic matter content. Besides, the litter produced by raru trees is also a source of organic material that can be used by fungi. Twenty fungal isolates were isolated from rhizosphere of raru trees where nine isolates showed cellulase activity characterized by the formation of clear zones around the colonies. The wider the clear zone produced by fungi, the greater the cellulase enzyme activity it produces. The clear zone formed is an indication that the fungi produce cellulase enzymes. Cellulase is an enzyme that is widely used. The cellulase enzymes, in addition to its use in food and industry (Kuhad et al. 2011), can also provide solutions in solving waste problems containing cellulose.

Based on morphological identification, nine isolates showing cellulolytic activity were included in two genera namely Aspergillus (5 isolates) and Penicillium (4 isolates). There were two Aspergillus isolates from rhizosphere of raru songal, two isolates from rhizosphere of raru dahanon and one isolate from rhizosphere of raru pulut, while for Penicillium, there were two isolates from rhizosphere of raru songal and each one isolated from rhizosphere of raru dahanon and raru pulut. Aspergillus and Penicillium are cellulolytic fungi which are mostly isolated by previous researchers both from the soil and from leaf litter (Herculano et al. 2011; Reddy et al. 2014; Torres et al. 2014; Sari et al. 2017). Molecular identification revealed five Aspergillus isolates consisted of three species, namely,
Aspergillus sp. (1FRS isolate), Aspergillus terreus (7FRS, 2FRD, and 4FRP isolates) and Aspergillus tanneri (9FRD isolate), and four Penicillium isolates consisted of 3 species, .i.e., Penicillium sp. (6FRS isolate), Penicillium mariae-crucis (8FRS and 10FRD isolates) and Penicillium citrinum (3FRD isolate). Aspergillus terreus was found in all three types of raru. According to Gandjar et al. (1999), A. terreus is a cosmopolitan fungus and commonly found in the tropics. These fungi are adaptable to various environmental conditions. The existence of cellulolytic fungi in the forest floor is very important because of its role in decomposing organic material containing cellulose found on the forest floor, and then transforming it into nutrients that can be taken by plants. Indirectly, the presence of cellulolytic fungi will support the growth of plants around it since the decomposition process will increase the nutrients available to the plants. The isolated cellulolytic fungi in this research have the potential to be used as an inoculum to accelerate the decomposition process of materials containing cellulose through composting process.

\section{ACKNOWLEDGEMENTS}

This study is part of a study on Raru (Cotylelobium spp.) funded by TALENTA Universitas Sumatera Utara 2018, Grant Number: 2590/UN5.1.R/PPM/2018 dated March 16, 2018.

\section{REFERENCES}

Ahmed MM, El-Zayat SA, El-Sayed MA. 2018. Cellulolytic activity of cellulose-decomposing fungi isolated from Aswan hot desert soil, Egypt. J Biol Stud 1 (2): 35-48.

Anderson IC, Parkin PI. 2007. Detection of active soil fungi by RT-PCR amplification of precursor rRNA molecules. J Microbiol Meth 68: 248-253.

Ashton PS. 1998. Cotylelobium melanoxylon. The IUCN Red List of Threatened Species 1998: e. T33070A9746855.

Bennett JW. 1998. Microtechnology: the role of fungi in biotechnology. J Biotechnol 66: 101-107.

Bao Z, Ikunaga Y, Matsushita Y, Morimoto S, Takada-Hoshino Y. 2012. Combined analyses of bacterial, fungal and nematode communities in Andosolic agricultural soils in Japan. Microbes Environ 27: 72-79.

Barstow M. 2019. Cotylelobium melanoxylon. The IUCN Red List of Threatened Species 2019: e.T33070A68069829. DOI: 10.2305/IUCN.UK.2019-1.RLTS.T33070A68069829.en.

Brigg JC. 2015. Species extinction: Frequency and biogeography. Environ Skeptics Critics 4 (4): 96-105.

David H, Hofmann G, Oliveira AP, Jarmer H. 2006. Metabolic networkk driven analysis of genome-wide transcription data from Aspergillus nidulans. Genome Biol 7. DOI: 10.1186/gb-2006-7-11-r108.

Gilman JC. 1971. A manual of soil fungi. The Low a State University Press, USA.

Gaddeyya G, Niharika PS, Bharathi P, Kumar PKR. 2012. Isolation and identification of soil mycoflora in different crop fields at Salur Mandal. Adv Appl Sci Res 3: 2020-2026.

Gandjar I, Samson RA, van den Tweel-Vermeulen K, Oetari A, Santoso I. 1999. Introduction of general tropical fungi. University of Indonesia, Depok. [Indonesian]

Hawksworth DL. 2011. Naming Aspergillus species: progress towardss one name for each species. Med Mycol 49: 70-76.

Hensel M, Holden DW. 1996. Molecular genetic approaches for the study of virulence in both pathogenic bacteria and fungi. Microbiol 142: 1049-1058. 
Herculano PN, Lima DMM, Fernandes MJS, Neves RP, Souza-Motta CM, Porto ALF. 2011. Isolation of cellulolytic fungi from waste of castor (Ricinus communis L.) Curr. Microbiol 62: 1416-1422.

Hossain MM, Sultana F, Kubota M, Koyama H, Hyakumachi M.2007. The plant growth-promoting fungus Penicillium simplicissimum GP17-2 induces resistance in Arabidopsis thaliana by activation of multiple defense signals. Plant Cell Physiol 48: 1724-1736.

Hyakumachi M. 1994. Plant-growth-promoting fungi from turfgrass rhizosphere with potentials for disease suppression. Soil Microorg 44: 53-68.

Khan SA, Hamayun M, Yoon H, Kim HY, Suh SJ, Hwang SK. 2008. Plant growth promotion and Penicillium citrinum. BMC Microbiol: 8 231. DOI: $10.1186 / 1471-2180-8-231$

Kim MJ, Lee H, Choi YS, Kim GH, Huh NY, Lee S, Lim YW, Kim JJ. 2011. Diversity of fungi in creosote-treated crosstie wastes and their resistance to polycyclic aromatic. hydrocarbons. J Microb 97: 377 387.

Krijgsheld P, Bleichrodt $\mathrm{R}$, van Veluw GJ, Wang F, Müller WH, Dijksterhuis J, Wösten HAB. 2013. Development in Aspergillus. Stud Mycol 74: 1-29.

Kubicek CP, Komon-Zelazowska M, Druzhinina IS. 2008. Fungal genus Hypocrea/Trichoderma: from barcodes to biodiversity. J Zhejiang Univ Sci B 9 (10): 753.

Kuhad RC, Gupta R, Singh A. 2011. Microbial Cellulases anT their Industrial Applications. Enzyme Res. DOI: 10.4601/2011/280696.

Soil Research Center. 2005. Chemical Analysis of Soil, Plants, Water and Fertilizer. Agricultural Research and Development Center. Agricultural Department, Bogor.

Landeweert R, Veenman C, Kuyper TW, Fritze H, Werners K, Smit E. 2003. Quantification of ectomycorrhizal mycelium in soil by re-l time PCR compared to conventional quantification techniques. FEMS Microbiol Ecol 45: 283-292.

Lima RF and Borba 2001. Viability, morphological characteristics and dimorphic ability of fungi preserved by different methods. Rev Iberoam Mycol 18: 191-196.

Madigan MT, Martinko JM, Parker J. 2012. Biology of Microorganism 8th ed. Prentice Hall International, Inc., New Jersey.

Maheswari NU, Komalavalli R. 2013. Diversity of soil fungi from Thiruvarur District, Tamil Nadu, India. Intl J Curr Microbiol App Sci 2: $135-141$.

Meena VS, Meena SK, Verma JP, Kumar A, Aeron A, Mishra PK, Bisht JK, Pattanayak A, Naveed M, Dotaniya MI. 2017. Plant beneficial rhizospheric microorganism (PBRM) strategies to improve nutrient use efficiency: A review. Ecol Eng 107: 8-32.

Möller C, Hansson A, Enberg B, Lobie PE, Norstedt G. 1992. Growth hormone $(\mathrm{GH})$ induction of tyrosine phosphorylation and activation of mitogen-activated protein kinases in cells transfected with rat $\mathrm{GH}$ receptor cDNA. J Biol Chem 267 (32): 23403-23408.

Monod M, Bontems O, Zaugg C, Chenne BL, Fratti M, Panizzon R. 2006. Fast and reliable PCR/sequencing/RFLP assay for identification of fungi in onychomycoses. J Med Microbiol 55: 1211-1216.

Mulani RM, Turkmane KL. 2014. Diversity of hizospheric fungi of Ceropegia bulbosa var. bulbosa Roxb. J Glob Biosci 3 (4): 10891093.

Nath D, Mauriya BR, Meena VS. 2017. Documentation of fire potassium and phosphosphorus solubilizing bacteria for their $\mathrm{K}$ and $\mathrm{P}$ solubilization ability from various mineral. Biocatal Agric Biotechnol 10: 174-181.

Punt PJ, van Biezen N, Conesa A, Albers A, Mangnus J, van den Hondel C. 2002. Filamentous fungi as cell factories for heterolo- gous protein production. Trends Biotechnol 20: 200-206.

Radhakrishnan R, Shim KB, Lee BW, Hwang CD, Pae SB, Park CH, Kim SU, Lee CK, Baek IY. 2013. IAA- producing Penicillium sp. NICS01 triggers plant growth and suppresses Fusarium sp.-induced oxidative stress in sesame (Sesamum indicum L.). J Microbiol Biotechnol 23: 856-863.

Rebecca LJ, Dhanalakshmi V, Sharmila S, Susithra G, Kumar S and Bala S. 2012. Isolation, identification and characterization of fungi from rhizosphere soil of Barleria Cristata. Intl J Hort Crop Sci Res 2: 1-6.

Reddy PLN, Babu BS, Radhaiah A, Sreeramulu A. 2014. Screening, identification, and isolation of cellulolytic fungi from soils of Chittoor District, India. Intl J Curr Microbial App Sci 3 (7): 761-771.

Rodríguez-Loinaz G, Onaindia M, Amezaga I, Mijangos I, Garbisu C. 2008. Relationship between vegetation diversity and soil functional diversity in native mixed-oak forests. Soil Biol Biochem 40 (1): 4960

Saraswati R, Husen E, Simanungkalit RDM. 2007. Soil Biological Analysis Method. Agricultural Research and Development Center. Agricultural Department, Bogor.

Sari SLA, Setyaningsih R, Wibowo NFA. 2017. Isolation and screening of cellulolytic fungi from Salacca zalacca leaf litter. Biodiversitas 18 (3): 1282-1288

Sartori FG, Leandro LF, Montanari LB, de Souza. 2013. Isolation and identification of environmental mycobacteria in the waters of a hemodialysis center. Curr Microbiol 67: 107-111.

Schoch CL, Seifert KA, Huhndorf S, Robert V, Spouge JL, Levesque CA. 2012. Nuclear ribosomal internal transcribed spacer (ITS) region as a universal DNA barcode marker for Fungi. Proc Nat Acad Sci USA 109: 6241-6246.

Segal BH, Romani L, Puccetti P. 2009. Chronic granulomatous disease. Cell Mol Life Sci 66: 553-558.

Shivanna MB, Meera MS, Hyakumachi M. 1996. Role of root colonization ability of plant grow-h promoting fungi in suppression of take-all and common root rot of wheat. Crop Prot 15: 497-504.

Sugui JA, Kwon-Chung KJ, Juvvadi PR. 2014. Aspergillus fumigatus and related species. Cold Spring Harb Perspect Med 5: a019786. DOI: 10.1101/cshperspect.a019786.

Sugui JA, Peterson SW, Clark LP, Nardone G, Folio L, Riedlinger G, Holland SM. 2012. Aspergillus tanneri sp. nov., a new pathogen that causes invasive disease refractory to antifungal therapy. J Clin Microbiol 50 (10): 3309-3317.

Susilowati A, Rachmat HH, Elfiati D, Kholibrina CR, Kusuma YS, Siregar H. 2019. Population structure of Cotylelobium melanoxylon within vegetation community in Bona Lumban Forest, Central Tapanuli, North Sumatra, Indonesia. Biodiversitas 20: 1681-1687.

Torres LMA, Pulido CPG, Rojas ET. 2014. Assessment of cellulolytic microorganisms in soils of Nevados Park, Colombia. Braz J Microbiol 45 (4): 1211-1220.

Tuli MS, Gurumayum S, Kaur S, Nagal S, Attri I. 2015. Isolation and screening of cellulolytic fungi by Baiting Method from Soil of Jalandar. Res J Pharm Biol Chem Sci 6 (2): 375-380.

Verma JP, Yadav J, Tiwari KN, Lavakush SV. 2010. Impact of plant grow-h promoting rhizobacteria on crop production. Intl J Agric Res 5: 954-983.

Verma R, Maurya BR, Meena VS, Dotaniya MI, Deewan P. 2017. Enhancing production potential of cabbage and improves soil fertility status of Indo-Gangetic Plant through application of bio-organics and mineral fertilizer. Intl J Curr Microbiol Appl Sci 6 (3): 301-309.

White TJ, Bruns T, Lee S, Taylor J. 1990. In: Innis A, Gelfand DH, Sninsky JJ (eds) PCR Protocols. Academic Press, San Diego, USA

Yadav K, Singh N, Aggarwal A. 2011. Influence of arbuscular mycorrhizal (AM) fungi on survival and development of micropropagated Acorus calamus L. during acclimatization. J Agric Technol 7: 775-781. 